\section{Re: Over Half of Graduating Family Medicine Residents Report More Than \$150,000 in Educational Debt}

To the Editor: We do a disservice to our medical students when we emphasize that their debt will affect their choice of specialty. ${ }^{1,2}$ From the day they matriculate students hear that their medical school debt is likely to affect their career choice. Throughout medical school, financial aid and career counselors bring this up again and again. Students hear the false dichotomy requiring them to choose between a generous income or primary care. Yes, the data show an association of debt with specialty choice. But there are tens of thousands of family doctors with hundreds of thousands of dollars of debt. Debt is not a factor in specialty choice for thousands of students each year. Bazemore et $\mathrm{al}^{2}$ report $>1800$ respondents chose family medicine despite $>\$ 150,000$ of debt, and nearly 800 made the choice of family medicine carrying $>\$ 250,000$ of debt. (That is $\$ 200,000,000$ of debt that did not affect career choice. And over the first 10 years of their careers these 800 family doctors will earn $>\$ 1.5$ billion).

While debt may affect some students' specialty choice, debt also may be used as an excuse by students who were planning to enter high-income specialties regardless. It is unlikely that debt is the deciding factor between choosing a career in family medicine versus ophthalmology or radiology. The more important issue for specialty choice may be medical school admissions. Who enters medical school may be a more potent predictor of specialty choice than how much debt they accumulate.

One wonders about these 800 individuals who entered family medicine despite their debt. What might we learn from them that can inform other medical students making career choices? And how do we get more of them into medical school?

Fixing the income disparities among primary care and specialty physicians is important. Getting the right people into medical school may be even more important. And helping students understand they have the choice to enter family medicine and still enjoy a comfortable income is crucial.

John M. Westfall, MD, MPH

Department of Family Medicine

University of Colorado School of Medicine, Aurora Jack.Westfall@ucdenver.edu

Kim Marvel, $\mathrm{PhD}$

Colorado Association of Family Medicine Residencies, Denver

\section{References}

1. Phillips J. The impact of debt on young family physicians: unanswered questions with critical implications. J Am Board Fam Med 2016;29:177-9.

2. Bazemore A, Peterson L, Jetty A, Wingrove P, Petterson S, Phillips R. Over half of graduating family medicine residents report more than $\$ 150,000$ in educational debt. J Am Board Fam Med 2016;29:180-1.

doi: $10.3122 /$ jabfm.2016.04.160097

The above letter was referred to the author of the article in question, who offers the following reply.

\section{Response: Re: Over Half of Graduating Family Medicine Residents Report More Than \$150,000 in Educational Debt}

To the Editor: Our thanks to Dr. Westfall for providing important comments on and context for this brief look at debt among family medicine residents. The brief ${ }^{1}$ was intended to highlight objectively a growing financial burden on those who do choose a career in family medicine and does not evaluate the degree to which that burden might affect or excuse the choices of others-though there exists a richer and more nuanced literature on that subject. Dr. Westfall's admiring interest in knowing more about those who select a discipline short in supply and remuneration relative to other specialties, and his suggestion that this is a contrarian choice worthy of our fascination, hints at a flawed approach to graduate medical education (GME) policy and planning in the United States.

As we've previously suggested, ${ }^{2}$ hospitals currently have every incentive to continue to make decisions about GME expansion based on their financial return rather than societal and population needs. This gives strong incentive to expanding lucrative subspecialty positions in areas with the most physicians, rather than giving needed attention to generalist positions in areas such as primary care, surgery, and psychiatry. Medical students in turn have clear incentives to follow suit, and debt is indeed but 1 of many factors influencing their decision making, and is very individual at that. The recent Institutes of Medicine report on GME calls for reforms to this market-driven-or, as Dr. Fitzhugh Mullan calls it, "anencephalic"-approach to GME planning. ${ }^{3}$ The Institutes of Medicine rec- 